\title{
VERSLO DERYBOS IR DALYKINIAI POKALBIAI: KOMUNIKACIJA DERĖJIMOSI PROCESE
}

\author{
Kęstutis Peleckis ${ }^{1}$, Valentina Peleckiené2 ${ }^{2}$ Aistė Mažeikiené $\dot{3}^{3}$ \\ ${ }^{1,2}$ Vilniaus Gedimino technikos universitetas, Sauletekio al. 11, LT-10223 Vilnius, Lietuva \\ ${ }^{3}$ Mykolo Romerio universitetas, Ateities g. 20, LT-08303 Vilnius, Lietuva \\ El.paštas: ${ }^{1}$ kestutis.peleckis@vgtu.lt; ${ }^{2}$ valentina.peleckiene@vgtu.lt; ${ }^{3}$ aiste.mazeikiene@mruni.eu
}

Iteikta 2011-12-01; priimta 2012-02-28

\begin{abstract}
Santrauka. Straipsnyje nagrinėjamos problemos, susijusios su nepakankamu derèjimosi proceso komunikacinių elementų sisteminiu suvokimu ir naudojimu. Apžvelgiama asmeninės komunikacijos, komunikacijos derybų ir dalykinių pokalbių procesuose apibrěžimų ịvairove ir jų loginiai ryšiai, pagrindiniai šių bendravimo procesų požymiai ir esminès savybès. Daug dèmesio skiriama derejimosi proceso tarpusavio supratimui siekiant bendro tikslo. Straipsnyje aptariamos dažniausiai pasitaikančios suvokimo klaidos derèjimosi procese ir pateikiamos priemonès joms išvengti. Derejimosi proceso komunikacijoje išryškinamas emocinis derejimosi aspektas, verbalinio ir neverbalinio poveikio priemonių derinimo būtinumas.
\end{abstract}

Reikšminiai žodžiai: verslo derybos, dalykiniai pokalbiai, komunikacija, derèjimasis.

\section{BUSINESS NEGOTIATIONS AND BUSINESS MEETINGS: COMMUNICATION IN THE BARGAINING PROCESS}

\author{
Kęstutis Peleckis ${ }^{1}$, Valentina Peleckiené2 ${ }^{2}$ Aistė Mažeikiené ${ }^{3}$ \\ ${ }^{1,2}$ Vilnius Gediminas Technical University, Sauletekio al. 11, LT-10223 Vilnius, Lithuania \\ ${ }^{3}$ Mykolas Romeris University, Ateities g. 20, LT-08303 Vilnius, Lithuania \\ E-mails: ${ }^{1}$ kestutis.peleckis@vgtu.lt (correspondingauthor); ${ }^{2}$ valentina.peleckiene@vgtu.lt; ${ }^{3}$ aiste.mazeikiene@mruni.eu \\ Received 01 December 2011; accepted 28 February 2012

\begin{abstract}
This article deals with the problems associated with lack of communication elements of the bargaining process, perception and usage. This article provides an overview of personal communication, communication in negotiations and business processes, a variety of definitions and their logical relations, the main features of these communication processes and essential properties. The article focuses on the bargaining process, mutual understanding in the process of achieving a common goal. The article discusses the most common errors in perception of bargaining process, and provides measures to prevent them. The bargaining process in communication highlights the emotional aspect of bargaining, the impact of verbal and nonverbal measures on harmonization.
\end{abstract}

Keywords: negotiations, business meetings, communication, bargaining.

JEL Classification: M21, M54. 


\section{Ivadas}

Aktualumas. Derettis versle tenka nuolatos: sudarant pirkimo-pardavimo sutartị, priimant ir atleidžiant darbuotoją, sprendžiant daugybę ìvairių situacijų. Dalykinis pokalbis ar derybos gali vykti lengvai arba su didele ịtampa, gali pavykti nesunkiai susitarti įveikiant ypatingus sunkumus arba visai nepavykti susitarti. Mokejimas dalykiškai bendrauti, suprasti kito žmogaus, derybų partnerio psichologiją, jo atstovaujamos organizacijos interesus daugiausia lemia dalykinio pokalbio ir derybų sèkmę. Norint tai gerai atlikti, reikia turèti bendravimo pagrindus, gebèti skaityti verbalinio ir neverbalinio bendravimo ženklus, išraiškas, turèti susikūrus pasiruošimo pokalbiui ir deryboms sistemą, gebèti pateikti ir gauti informaciją, argumentuoti savo pozicijas, atsakyti i pastabas, jas neutralizuoti, perprasti, nepasiduoti manipuliacijoms ir mokèti dalykini pokalbi ar derybas kaip dera užbaigti.

Problema. Kai kurių komunikacijos elementų svarbos derybiniame procese neịvertinimas, komunikacijos teorinių žinių ir iggūdžių stoka gali tapti esmine kliūtimi efektyviems derybų rezultatams pasiekti.

Tyrimo objektas - komunikacija derejimosi procese.

Darbo tikslas - atskleisti svarbiausius derèjimosi proceso komunikacinius elementus, leidžiančius efektyvinti verslo derybas ir dalykinius pokalbius.

Tyrimo metodai - mokslinès literatūros sisteminé, lyginamoji, loginè analizè ir sintezè.

\section{Verslo derybos ir dalykiniai pokalbiai komunikacijų sistemoje}

Verslo derybos ir dalykiniai pokalbiai - sudètingas daugiaplanis, daugialypis procesas, kuriame derinami ir sprendžiami besiskiriantys, o dažnai ir prieštaringi besiderančiu šalių interesai (Aguinis et al. 1998; Anderson, Bowman 1999; Bailenson, Beall 2006). Šalys siekia rasti tokị kompromisinị sprendimo variantą, kuris geriausiai atitiktų jų tikslus ir interesus. Tai reiškia, kad besiderančios šalys turi mokèti ieškoti sprendimų variantų, juos vertinti, tarpusavyje lyginti, parinkti iš jų geriausią, abiem pusėms priimtiną (Bailenson et al., 2001; 2003; 2004; 2005; Ginevičius 2009; Lobanova 2009; Jurevičiené, Komarova 2010; Smaliukienè et al. 2010; Zabielavičienè 2008). Tam reikia mokèti valdyti derejjimosi procesą, ruoštis deryboms kaip sprendimo paieškos procesui, gebèti pasirinkti efektyviausią derẻjimosi strategiją ir taktinius jos realizavimo žingsnius, planuoti derybų fazes ir etapus (Barg 1994; Bucy 2000; Burgoon, Bacue 2003; Burgoon et al. 2000; Burgoon, Dunbar 2000).

Kita vertus, derybos - jų dalyvių komunikacijos, bendravimo procesas. Šiuo požiūriu derybų rezultatyvumas priklauso nuo to, kaip šalys vieną kitą supranta, kokia informacija viena apie kitą disponuoja ir išgauna derèjimosi procese, kaip joms pavyksta išsiaiškinti viena kitos elgesio motyvus, geba pateikti pasiūlymus, argumentus, ittikinti kitą pusę.

Derëjimasis - potencialiai konfliktiškas procesas. Todèl derybininkas turi turèti savo arsenale priemonių, kurios neleistų konfliktui ịsiliepsnoti, o jam ịvykus mokèti išeiti iš tokios situacijos, išspręsti konfliktą, orientuojantis ị ilgalaikius santykius su derybu partneriu (Cherulnik et al. 2001; Choi et al. Driskell, Salas 2005; Dunbar, Burgoon 2005a, 2005b).

Savo ruožtu verslo derybos, dalykinis pokalbis - asmenybių sąveika. Ši sąveika gali vykti kovos arba bendradarbiavimo forma. Galima pačiam vadovauti derèjimosi procesui arba galima leistis būti vadovaujamam kito asmens, pasiduoti įtakai. Galima pačiam formuluoti žaidimo taisykles arba priimti kitos pusés primetamas sąlygas. Geras derybininkas turi mokèti atsispirti itakai ir manipuliacijoms, argumentuoti ir apginti savo pasiūlymus, nepasiduoti spaudimui, oponentą paversti partneriu, derybinèje situacijoje iš kovos pozicijų pereiti ị bendradarbiavimo vèžes.

Komunikacijos formos ir kanalai šiame amžiuje tobulèja labai sparčiai, o ekonominès ir visos kitos gyvenimo krizès reikalauja spartinti naujų komunikacijos priemonių ir technologijų plètrą. Tačiau gyvo dalykinio pokalbio ir betarpiškų derybų reikšmè ir toliau išlieka labai svarbi. Svarbiausi ir lemtingiausi susitarimai vyksta ir dar ilgai vyks susitinkant akis ị akị. Pokalbis - vienas iš geriausių ir priimtiniausių būdų įtikinti pašnekovą savo pozicijos pagrịstumu, kad jis pats sutiktų su oponento pozicija ir ją priimtų ar palaikytų (Peleckis et al. 2010, 2011a; 2011b; Peleckis, Mažeikienè 2009).

Kuo daugiau komunikacijos priemonių i̇valdome, tuo dažniau patys nustembame patyrę (dažniausiai pavèluotai), kad žodžiai ne visuomet pasiekia tikslą. Be to, pasakyti žodžiai pašnekovams ne visuomet reiškia tą patị, ką ir... mums. Tuo labiau, kad ne visi turime talentą kalbèdami uždegti žmonių širdis ir pažadinti mintis. Lyg ir žinome teoriškai, kaip sustiprinti žodžių ịtaigą, jų poveikị, kokios vartojimo žodžių galimybès ir kaip valdyti kūną, gestus, mimiką, tačiau ką daryti, kad dalykinis bendravimas nevirstų ,"sugedusiu telefonu“ ir galiausiai pasiektume asmeninius ar organizacijos tikslus?

Daugelis verslo vadovų ir specialistų efektyvią komunikaciją derejimosi procese verslo derybų ir dalykinių pokalbių meistriškumą mini kaip būtiną sẻkmės recepto sąlygą.

Turbūt ne kartą esame patyrę, kad svarbaus pokalbio metu viskas reikšminga: žodžiai, gestai, mimika, aplinka, apranga, laikysena. Šių veiksmingai kontroliuojamų dalykų visuma gali sẻkmingai (arba nesėkmingai) kurti mūsų ivaizdi.

Verslo derybų ir dalykinių pokalbių mokslas ir menas apima daugybės mokslų žinias: komunikacijos, retorikos, psichologijos, etikos, vadybos, ekonomikos. Šių mokslų žinių jungtis suteikia galimybę komunikacijos ir kalbos 
galimybes atskleisti daug geriau, nei kartais girdime ir stebime aplink. Ir tam pasiekti nereikia didelių atradimų. Verta žinoti pagrindinius derejjimosi proceso komunikacijos ir poveikio elementus ir juos taikyti.

Komunikacijos, derybų ir dalykinių pokalbių apibrèžimų yra didelè įvairovè (kai kurie autoriai pateikia beveik 100 komunikacijos apibrèžimų), tačiau svarbi yra jų loginè seka (kas iš ko kyla ir formuojasi toliau) ir praktinis palyginimas. Pagrindiniai šių sudètingų bendravimo procesų požymiai ir apibrèžimai pateikti lenteleje.

Komunikacija apskritai, o kartu ir derèjimosi proceso komunikacija turi būti abipusè. Derẻjimasis yra komunikacijos procesas, kuriame ne mažiau kaip dvi šalys siekia abiem pusėms priimtino susitarimo. Verslo derybose ir dalykiniuose pokalbiuose pasireiškia asmenų ar grupių poveikis vienas kitam (Pipirienè, Maciukevičienè 2011). Tas poveikis atliekamas tiek verbaliniu, tiek neverbaliniu būdais. Derantis siekiama paveikti oponento mąstymą, ̨̇tikinti ji, kad tam tikri pokyčiai padès pasiekti bendrą tikslą ir abiem pusèms naudingą sutarimą. Informacijos priemėjas gaunamą informaciją dekoduoja, apdoroja ir pats siunčia savo informaciją. Tai - grị̌ztamasis ryšys, kuris pakoreguoja siunčiamos informacijos supratimą. Jei komunikacija tęsiasi sèkmingai, siuntėjo ir prièmejo informacijos dekodavimai vis labiau sutampa, vadinasi, jie rado bendrą kalbą. Tačiau ne visada taip i̇vyksta. Draugiškas patarimas ar naudingas pasiūlymas gali būti suprastas kaip kritika, pokštas, galintis jžeisti, pastaba gali virsti priekaištu. Šis suvokimas priklauso nuo asmenybès veiksnių - emocinès patirties, nuotaikos, vertybių.

Pagal bendravimo stilių, situaciją, sąlygas komunikacija derejimosi procese gali būti:

1) vienpusé: kalbètojas pateikia klausytojams informaciją ir nesiekia grižžtamojo ryšio;

2) dvipusè: laisvai keičiamasi idejjomis. Ši komunikacija užima daugiausia laiko, bet yra labai veiksminga;

3) vienpusè komunikacija su grįžtamuoju ryšiu: kalbètojas pateikia informaciją ir klausia, kaip ji suprasta.

Pagal informacijos perdavimo derejimosi procese intenciją komunikacija gali būti tikslinè ir netiksliné, pagal rezultatyvumą - veiksminga ir neveiksminga.

Pagal veiksmingumo lygị komunikacija derejjimosi procese gali būti skirstoma taip:

1 lygis - veiksmingiausia - tiesiogine (vykstanti akis $i$ $a k i)$, kai keičiamasi informacija per tiesioginį kontaktą, naudojant verbalinius (žodinius) ir neverbalinius simbolius. Iš karto betarpiškai atsirandantis momentinis grižtamasis ryšys užtikrina veiksmingą bendravimą.

2 lygis - mažiau veiksminga, kai komunikacijos partneriai atskirti erdveje ir sąlygiškai laike (vykstanti telefonu, elektroniniu paštu, skaipo sistema ir pan.).

3 lygis - mažiausiai veiksminga yra netiesiogine (sudètingiausia) raštiška komunikacija (pašto paslaugu sritis), kai partneriai atskirti laike ir erdvejje ir nèra jokio momentinio grịžtamojo ryšio arba dar blogiau - kartais gavejją ryšys pasiekia per vèlai; gavejjas sureaguoja, tačiau situacija jau būna pasikeitusi, galima sakyti - šaukštai po pietų.

\section{Suvokimo klaidos derèjimosi procese}

Išskiriamos šios būdingiausios suvokimo klaidos derejjimosi procese:

1) dalis informacijos praleidžiama;

2) kai kurioms detalèms suteikiama per daug reikšmès;

3) neteisingai interpretuojame ryšius tarp atskirų suvokiamų elementų;

4) daromos neteisingos prielaidos apie žmones, remiantis akstesne patirtimi ir klaidingai manant, kad kai kurie būdo bruožai turi būti visada susiję su kitais.

Norint išvengti suvokimo klaidų derejimosi procese, reikia:

a) būti lankstiems, gebèti keisti nuomonę apie žmogų, sužinojus ką nors naujo. Tai padètų išvengti aureolés efekto kai dalis gautos informacijos apie žmogų ima dominuoti ir daro įtaką galutiniam sprendimui. Pavyzdžiui, pastebëję labai patrauklų asmens bruožą, esame linkę nepastebèti jo trūkumų ir ieškome kitu patrauklių savybių, siekdami susidaryti kuo teigiamesnį asmens vaizdą. Ir priešingai, jei pastebime ką nors atstumiančio, ieškome ir daugiau patvirtinimų, kad tas asmuo apskritai yra neigiamas. Igijus lankstumo vertinant, pavyktų išvengti ir stereotipų poveikio;

b) atidžiai stebèti ir sekti detales, skirti joms dèmesio: ir žodiniams, ir nežodiniams pranešimams bei aplinkybėms, kurioms esant bendraujama. Reikia nuolat tikrinti gaunamą informaciją ir lyginti su tuo, ką pastebime, su turima nuomone, atkreipiant dèmeși i prieštaringus dalykus, kurių apstu bendravimo procese. Taip išvengtume apgaulingo nuoseklumo iliuzijos (angl. False consistency), kai nepagrịstai tikimès, kad kito asmens elgesys bus nuoseklus: vienas jo poelgis neprieštaraus kitam, panašiomis situacijomis jis visuomet elgsis taip pat ir pan. Todèl kartą iš ko nors išgirdę stačiokišką frazę: „Man jau pakaks šių nesąmonių“, kol kas nemanykime, kad tas žmogus - arogantiškas nepraustaburnis, nors tąkart jis gal tiesiog stačiokiškai pajuokavo;

c) reikia mokèti atidèti sprendimą, t. y. reikia stengtis kuo ilgiau nedaryti galutinio, lemiamo sprendimo, sukaupti apie ji kuo daugiau ir ịvairiapusiškesnès informacijos ir apgalvoti, kaip reaguoti pačiam;

d) skirti laiko papildomai informacijai rinkti, kuri padètų susidaryti objektyvesnę nuomonę;

e) nepasiduoti pirmojo įspūdžio (pradmès) ir baigmès poveikiui. Daugeliu tyrimų nustatyta, kad ir pačius pirmuosius, ir paskutinius žmonių žodžius bei poelgius ịsimename geriau nei vidurinius ir jais labiau pasitikime, spręsdami apie žmones. Pvz., jei vienos derybos baigèsi nesèkmingai, tai nebūtinai reiškia, kad ir visos kitos derybos su šiuo žmogumi bus tokios, kad neverta nei pradèti. Nors nemalonius 
Lentelè. Asmeninè ir dalykinè komunikacija: palyginimas su dalykiniu pokalbiu ir derybomis

Table. Personal and business communication: a comparison with business meetings and negotiations

\begin{tabular}{l} 
Apibrèžimas \\
\hline Komunikacija (lot. comunicatio - \\
pranešimas, perdavimas): \\
a) procesas, reikalingas socialinio \\
gyvenimo analizei; \\
b) žinios gavejui apie tam tikrą dalyką \\
siuntimas. Žinios siuntejjas ketina \\
perduoti tam tikrą informaciją; gavejas \\
turi motyvą, iš jo laukiama kokių nors \\
santykių - komunikacinio efekto; \\
Komunikacija - tai keitimasis \\
sukurta / apdorota informacija tarp \\
dvieju ir daugiau žmonių, siekiant \\
bendro supratimo.
\end{tabular}

Asmeninè komunikacija yra neformali tai keitimasis informacija asmeninio pobūdžio klausimais.

Dalykine komunikacija yra formali - tai keitimasis informacija platesniu mastu, prasmès perteikimas ịvairiais simboliais, susijusiais su vidinių ir išorinių žinių perdavimu ir gavimu žodžiu, raštu ir neverbaliniu būdu organizuotose žmonių grupèse arba tarp organizuotų žmonių grupių.

\begin{tabular}{|l|}
\multicolumn{1}{|c|}{ Tikslai ir funkcijos } \\
a) ịrankis informacijai perduoti \\
bendraujant; \\
b) būdas priimti žinias; \\
c) būdas kurti socialinius \\
santykius tarp proceso dalyvių; \\
d) keitimasis psichinès veiklos \\
rezultatais (žiniomis, mintimis, \\
sprendimais, vaizdiniais, \\
patirtimi, jausmais, nuostatomis \\
ir kt.); \\
e) veiksmų derinimas, \\
tarpusavio poveikis; \\
f) tarpusavio supratimas \\
(socialinè percepcija). \\
\hline
\end{tabular}

Draugystė, bičiulyste, kurios

svarbiausias dalykas yra

tarpusavio patrauklumas.

Žinių, nuomonių, kuriomis

žmonès keičiasi, tikslinimas ir

plètimas. Tuo naudodamiesi

organizacijos nariai:

a) gali tinkamiau reaguoti

ì pokyčius organizacijoje,

prisitaikyti prie kintančių

užduočių;

b) turi galimybę pažinti situaciją,

spręsti kylančias problemas;

c) labiau motyvuotai siekti bendrų tikslų.

\section{Dalykiniai pokalbiai yra:}

a) būdas spręsti klausimus, pasitelkiant žodinị kontaktą tarp oponentų, partnerių (pašnekovų), kurie turi grupès ar organizacijos igaliojimus spręsti kilusias problemas;

b) apgalvotas vieno ar grupès žmonių siekis žodžiu daryti ịtaką kitam žmogui ar žmonių grupei, siekiant paveikti kurią nors pusę tam tikroje situacijoje ir pakeisti pašnekovų santykius.

Derybos - dalykinio bendravimo procesas, kuriam vykstant partneriai, remdamiesi skirtingais tikslais ir pozicijomis, siekia rasti abiem šalims tinkamą sprendimą. Palankus derybų rezultatas leidžia skirtingus tikslus turinčioms pusèms siekti savų interesų. Derybos dar apibrèžiamos kaip mainai. a) pradèti kokią nors veiklą;

b) kontroliuoti veiklą;

c) keistis informacija;

d) spręsti kilusią problemą;

e) skatinti veiklą ir kelti naujas

idejas;

f) kurti tarpusavio santykius;

g) palaikyti ir plètoti santykius.

a) méginti suderinti pirmosios pusès požiūriu gerą rezultatą su antrosios derybų pusès požiūriu geru rezultatu;

b) pasiekti, kad kiekviena puse gautų ką nors vertingo mainais už daromą nuolaidą.

Tikslai pagal prioritetus skirstomi i grupes:

- kuriuos pasiekti būtų idealu;

- kuriuos pasiekti realu;

- kuriuos pasiekus atsirastu

jausmas, kad derybos buvo nesèkmingos. d) laisvas abiejų bendraujančių partnerių vienas kito pasirinkimas;

e) vienas kito poreikių tenkinimas bendraujant.

a) dažniausiai - formali organizacijos veikla;

b) santykiai su formalia organizacija;

c) tam tikrų igaliojimų ir (arba) issipareigojimų turejjimas. a) bendra aplinka - socialinè, fiziné, laiko erdvé, supanti dalyvius;

b) tam tikras laikas, pvz., komanda ar pasisveikinimas gali trukti trumpai, bet ir gavejo;

c) situacijos pokyčiai: kintantys dalyvių tarpusavio santykiai ir išorine aplinka; 
derybų partnerio pareikštus priekaištus derybų pabaigoje prisimename labiau nei susitikimo pradžioje išsakytus komplimentus (baigmés efektas), kitos derybos turètų prasidèti nuo nulio - kartais palankų derybų rezultatą galime pasiekti tik atsikratę ankstesnès patirties, neatsižvelgdami į buvusiuose susitikimuose išsakytus žodžius, tačiau turedami galvoje pašnekovų pažinimą... Laikas ir aplinkybių kaita keičia ir situaciją, ir derybų partnerio tikslus, ir interesų sritis, tad kitoje vietoje ir kitu laiku, atsikratę neigiamų ankstesnių derybų patirties, geriau pasiruošę ir labiau pažindami derybų partnerị kaip asmenybę, galime sèkmingiau rasti interesų sutapimo taškus ir siekti abipusio laimejjimo;

f) pabandyti ịsijausti - pažvelgti i situaciją kito žmogaus akimis, suprasti jo padètị. Iš tikrujuų tol, kol patys nebuvome patekę í ilgalaikio bedarbio, apvogto vadovo, bendravimo stokojančio vienišiaus, sunkaus ligonio, nekaltai teisiamojo padètį, ne visada galime tiksliai suprasti šių žmonių reakcijas ir intensyvias emocijas. Pvz., derybų metu oponentą gali erzinti pašnekovo pedantiškumas, gilinimasis ị smulkmenas, įdèmus, netgi įtarus žvilgsnis, jam išgirdus bet koki naujesnị dalyką. Bet tai nereiškia, kad turi pritrūkti kantrybès įrodinèti, pateikti jam išsamius duomenis ir pagrịsti faktus - gali būti, kad šţ̌žmogų iki šiol tiesiog supo nepatikimi partneriai, galbūt jis yra patyręs apgaulę ir su ja susijusių nuostolių ar ilgą laiką dirbo tokioje aplinkoje, kur tik ir ieškota jo silpnųjų pusių ir bandyta tuo pasinaudoti. Reikia stengtis rasti ne vieną, bet keletą skirtingų paaiškinimų, kodèl žmogus pasielgè vienaip, o ne kitaip, atkreipti dėmesi ir ị vidinius (pvz., galbūt jis piktas todèl, kad jam šiandien ištraukè dantị, jis alkanas, o vakare dar laukia ilgas akcininkų susirinkimas, per kurị jis gali gauti pasiūlymą palikti postą, ar galbūt jis visiškai nepasiruošęs šioms deryboms, net nèra perskaitęs gautos informacijos), ir ị išorinius (gal sugedo automobilis, vaikų nèra kam paimti iš darželio, jam per karšta) jo elgesi galinčius lemti veiksnius.

\section{Emocinis derèjimosi aspektas}

Verslo derybose ir dalykiniuose pokalbiuose negalima nè minutei pamiršti emocinio bendravimo aspekto. Kyla klausimas, kodèl derèjimosi proceso komunikacijoje svarbios emocijos? Kaip rodo praktika, būtent emociniai dalykai dažnai viską sugadina arba, priešingai, konstruktyviai paspartina susitarimus ir palengvina bendradarbiavimą (Ekman 1997; Hecht et al. 1999; Izard 1997; Manusov 1999; Parkinson et al. 2005; Riggio 2005).

Galimas dvejopas reagavimas ị kitą žmogų ir jo problemas: kognityvinis (informacinis, mąstymo) ir emocinis. Tam tikrais atvejais mums reikia žmogaus, kuris galètų suteikti reikalingos informacijos, išmintingai patarti, analizuodamas problemą, rasti objektyvių faktų, rodančių, kaip ịklimpta ị informacijos liūną. Kitais atvejais labiau reikia emocinès paramos, supratimo, užuojautos, išklausymo.
Emocinè parama vadinama empatija - įsijautimu ị kito žmogaus emocinę būseną ir išgyvenimu to, ką jaučia kitas. Išskiriamos trys empatijos fazès:

1) supratimas, kito žmogaus emocinès būsenos pajautimas. Svarbu ne tik sugebèti, bet ir norèti gilintis ị kito žmogaus jausmus. Ypač derybose, dalykiniuose pokalbiuose reikia stengtis suprasti, ką išgyvena pašnekovas - tik taip galima sužinoti, kas jam svarbiausia, kokios yra silpnosios derybų partnerio pusès, kurias galima paveikti ir padèti, pvz., derybų metu pašalinti nesaugumo, priešiškumo ar nepasitikèjimo priežastis;

2) kito žmogaus jausmo išgyvenimas. Atrodytų, kad empatiškas žmogus džiaugiasi, rūpinasi kitu labiau nei savimi pačiu. Ne tik motinos džiaugiasi savo vaiko sėkme ir rūpinasi dèl jų nesèkmių labiau nei patys vaikai. Kiekvienose derybose labai naudinga balsu svarstyti, ką iš vieno ar kito sprendimo gauna kiti derybų dalyviai, galvoti tarsi už juos, žinoma, nepamirštant ir savo interesų.

3) jausmo perdavimas įvairiomis išraiškos priemonèmis. Supratimo parodymas - būtina pasitikèjimo bet kokiuose dalykiniuose santykiuose kūrimo sąlyga, jau nekalbant apie asmeninius santykius

Empatija, kaip ne tik artimo, bet kai kuriais atvejais ir dalykinio bendravimo sąlyga, yra ne igimta, bet išugdoma savybè. Jos priešingybè būtų egocentriškumas - toks paskendimas savo problemose ir rūpesčiuose, kad net neskiriama laiko pastebèti, jog kiti žmonès taip pat turi problemų, noru ir interesų (Bucy 2000; Parkinson et al. 2005). Derybose egocentriškumas gali tapti pavojingas: jei bandysime pasiekti vien tik savo tikslus (žinoma, jų jokiu būdu negalima pamiršti - kam gi tada derètis?), o tai pastebès kita derybų puse, derybų rezultato galime ir nepasiekti

\section{Verbalinẻ komunikacija derèjimosi procese}

Žmonių komunikacija vyksta skirtingomis formomis, kurių pagrindinès yra verbalinè ir neverbalinè. Dauguma tyrejju mano, kad verbalinis kanalas naudojamas informacijai perduoti, o neverbalinis apibrèžia tarpasmeninius santykius, o kartais net atlieka žodinio pranešimo funkciją.

Verbalinè komunikacija - tai tarpusavio sąveika, informacinis elgesys, kalbos ženklus tarp dviejų ar daugiau žmonių naudojant kaip simbolius idejoms išreikšti. Verbalinè komunikacija vyksta tada, kai bendraujama kalbos simboliais žodžiu ir raštu. Teoriškai dalykiniai pokalbiai yra ar bent jau turetų būti tikslingai parinktų žodžių rinkinys, kuriais vienas ar keli pašnekovai nori paveikti kitą pašnekovą ar jų grupę, turint tikslą pakeisti esamą dalykinę situaciją ar santykius, t. y. kurti naują situaciją ir santykius.

Neverbalinè komunikacija vyksta informaciją perduodant vaizdais. Tai gali būti ženklų kalba, veiksmų kalba, gestai, išvaizda, balso kokybe, veido išraiška, erdvès pasidalijimas, laiko paskirstymas. 
Pagrindinès verbalinės komunikacijos funkcijos yra šios:

- informacinè (informacijos perdavimas, minčiu, ketinimų pranešimas);

- agitacinè (skatinimas, prašymas);

- emocinè (jausmai).

Vykstant verbalinei komunikacijai, turime užtikrinti veiksmingą informacijos perdavimą. Pagrindinès verbalinès komunikacijos rūšys - kalba, rašymas ir bendravimas elektroninėmis priemonėmis, taigi rašytinès ir žodinès priemonès. Rašytinè komunikacija vyksta tuomet, kai informacijai perduoti pasitelkiamas raštas. Rašymas - patogus ir rašančiajam, ir skaitančiajam, nes skaityti ir rašyti galime, kai tik panorime.

Verslo derybų ir dalykinių pokalbių atveju akcentuojama žodiné verbalinè komunikacija formaliame ir dalykiniame kontekste. Toliau aptarsime veiksmingo kalbejjimo svarbą, igūdžius ir jų ugdymo galimybę.

Kalbejiimas - tai visų pirma improvizacija. Priešingai, negu rašant, galimi netiketumai - nenumatytos pašnekovo reakcijos, aplinkos pasikeitimai, galiausiai - net stiprus kosulio priepuolis, galintis priversti nutraukti susitikimą. Juk ne visuomet galima pasirinkti patogų kalbèjimo laiką, spèti pasiruošti kalbèti visomis galimomis temomis ir sugebèti išreikšti mintis. Dèl šios priežasties siuntėjas geriau kontroliuoja rašomą pranešimą. Rašantis asmuo turi laiko aiškiai išreikšti mintis, o kalbantis - gali pavartoti ir neaiškiu sąvokų. Rašant renkama medžiaga, apmąstoma problema, suplanuojama ir vèliau viskas perrašoma - tai užduotys, kurioms atlikti spontaniškai kalbètojas neturi laiko. Rašant išlaikomas didelis atstumas tarp siuntėjo ir gavejo - grižztamasis ryšys gali vèluoti valandas ar net jo nebūti. Didelis skirtumas tarp kalbẻjimo ir rašymo yra tas, kad kalbejjimas nepalieka jokių pèdsakų - įrašų. Dèl šios priežasties formaliu komunikaciju metu labiau pasitikima rašytine informacija. Pvz., sklandant gandams, plintant klaidinamai informacijai rekomenduojama pasirinkti rašytinès komunikacijos büdus ir priemones.

Tačiau verbalinè komunikacija gali būti daug veiksmingesnè, siekiant paveikti kitų žmonių nuomonę ir pasiekti susitarimą - kadangi kalbètojas ir klausytojas sąveikauja tiesiogiai, kalbètojas gauna betarpišką grižtamąjį ryšį ir gali priderinti savo pranešimą prie situacijos. Asmuo, parašęs, pvz., laišką, gali atsidurti situacijoje, kai daug kas jau per vèlu.

Pagal komunikavimo turini derèjimosi procese gali būti išskiriami penki pagrindiniai verbalinio bendravimo būdai: 1) aiškinamasis bendravimas - pasakome pašnekovui, ką, mūsų manymu, reiškia vienas ar kitas reiškinys, ta ar kita situacija;2) palaikomojo bendravimo atveju siekiame parodyti aplinkiniams, kad norime jiems gero, stengiamès padèti; 3) tyrinejamasis bendravimas - tai siekimas gauti daugiau informacijos apie pašnekovą, klausytoją, derybų partnerius; 4) savitarpio supratimas - tai toks bendravimo būdas, kai stengiamès geriau suprasti, ką kitas žmogus sako ar jaučia; 5) įvertinamasis bendravimas reiškia, kad kalbėdami ịvertiname kokị nors žmogų, daiktą, reiškinį, situaciją, priskiriame juos tam tikrai kategorijai: pasakome, ar jis geras ar blogas; teisingas ar neteisingas; tinkamas ar netinkamas. Verbalinè komunikacija - pagrindiné dalykinès komunikacijos ir svarbi paties verslo sudedamoji dalis: kuo aukštesnes pareigas norime užimti organizacijoje ir kuo aukštesnių rezultatų trokštame pasiekti, tuo labiau privalome mokèti bendrauti. Būtent per verbalinę komunikaciją galime atskleisti profesinę kompetenciją, sukurti i̇vaizdį ir... j̇veikti konkurentus. Tas pats pasakytina ir apie verslo derybų ar dalykinių pokalbių rezultatyvumą. Kai kalbame ta pačia kalba, vieni kitus lengvai galime suprasti. Kitaip būtų galima pasakyti, kad kalbamès suprantamais tos kalbos žodžiais (kodais). Jei žmonėms tie kodai nesuprantami, jie negali tarpusavyje bendrauti. Jei vienas žmogus kalba, o kitas, klausydamas jo, visiškai nesupranta tos kalbos, tai, žinoma, jie bendrauti negalès. Tačiau ir ta pačia kalba bendraujant gali pasitaikyti nesusipratimų. Tie patys žodžiai dažnai yra skirtingos reikšmès, dèl to žmonès gali juos nevienodai suprasti. Pavyzdys galètų būti techniniai žodžiai, slengas. Kai kurie žodžiai vieniems yra iprasti ir priimtini visada, o kitiems - tik tam tikroje situacijoje. Turint tai galvoje ir siekiant bendravimą padaryti veiksmingesni verbalineje komunikacijoje svarbu suderinti ir suvienodinti reikšmes, prasmę. Derëjimosi procese svarbu sugebèti sukelti ir išlaikyti oponento susidomèjimą. Tam tinka „dozuojamoji“ pokalbio strategija ir taktiniai ,atsitraukimo" veiksmai. Čia reikia atsižvelgti ị tai, kad mūsų oponentas yra smalsus: jis nori pats kuo daugiau išsiaškinti, sužinoti. Jeigu jam viską pateiksime ,ant lèkštutès“ - mes iš jo atimsime galimybę pačiam ieškoti atsakymų i r rūpimus klausimus. Oponento dèmesị sužadinsime tada, kai leisime jam pačiam pasireikšti. Ilgesnèse verslo derybose ar dalykiniuose pokalbiuose oponento susidomèjimą galima sužadinti ir kelis kartus sudominant, o paskui šiek tiek atsitraukiant, kad palaikytą reikalingą derẻjimosi ịtampą. Tai padès oponentui pačiam daryti reikalingus žingsnius, kad išsiaiškintų jam svarbius dalykus. Derejjimosi procese svarbu išlaikyti pokalbio dinamiškumą. Čia gali padeti tam tikrų detalių, elementų sureikšminimas. Kaip pažymi Stefan Spies, dinamiškumo ịspūdị galima kurti savo statuso kaitaliojimu: kartkarčiais nusižeminant ir leidžiant kitiems aktyviau dalyvauti pokalbyje, rinkti reikalingą informaciją ir mėginti pralaužti oponeto santūrumo skydą. Paskui vèl reikètų šiek tiek pakilti i aukštesnị statusą ir mèginti derybų partneri provokuoti, kritikuoti arba sudominti savo pasiūlymu. Dinamiškumo įspūdi gali padèti kurti ir mūsų kūnas, jei oponentui kartais duosime galimybę reikštis, o tada vèl ją atimsime (Spies 2006: 196). 


\section{Neverbalinė komunikacija derẻjimosi procese}

Poveikị žmonėms 93 proc. lemia kūno kalba ir balsas (Spies 2006: 1).

Kaip pažymi Stefan Spies, „kūno signalus valdo mintys, o ne išoriniai dirgikliai, todèl tik vidinis nusiteikimas padeda ittikinamai ir savitai reikštis darbe bei asmeniniame gyvenime“ (Spies 2006: 1). Kita vertus, kūno padètis ir laikysena veikia ir emocinę žmogaus būseną, jo santykị su supančiu pasauliu, todèl tarpusavio santykiuose ji turi didelę reikšmę. Kūno pozos ne tik kuria tam tikrą ỉspūdį mus stebinčiam pašnekovui ar klausytojams, bet ir veikia savęs suvokimą, mūsų pačiu tikslų nustatymą ir elgesio strategijos pasirinkimą.

Dažnai pažintis užsimezga per kūno kalbą (kūnų padèties sinchronizacija, judejjimas, rankos paspaudimas). Dalykinè pažintis taip pat gali užsimegzti per neverbalinę kalbą! Tai reiškia gebẻjimą pajusti pašnekovą ir netgi nuspèti kitą jo judesị (Aguinis et al. 1998).

Ar pastebejote, kad žmonès gestikuliuoja netgi kalbèdami telefonu, kai jų pašnekovas nemato? Kai, pvz., aiškina, kaip rasti kelią? Arba aiškindamiesi, kaip atrodo trikampio figūra - juk braižo rankomis trikampį ore! Ar ịsivaizduojate, ką darytume, jei kalbant būtų surištos rankos? Juk jos padeda pabrèžti, akcentuoti tai, ką pasakome žodžiais.

Žinoma, būtų labai naudinga žinoti ir atpažinti individualią ir situacijos nulemtą kūno kalbą.

Dauguma neverbalinio elgesio gestų yra ịgyti, o jų reikšmę lemia kultūra. Visame pasaulyje kai kurie pagrindiniai komunikacijos gestai yra vienodi. Kai žmonès laimingi, jie šypsosi, kai liūdni - tampa paniurę, kai niršta - žvilgsnis būna piktas. Tačiau net ir galvos linkčiojimas ne visame pasaulyje reiškia „taip“ arba patvirtinimą (norint įsitikinti, pakanka nuvažiuoti į Bulgariją), nors, atrodytų, kad galvos linkčiojimas - lyg ir igimtas gestas, nes jị naudoja ir kurti, ir akli žmonès. Galvos purtymas, reiškiantis neigimą, taip pat beveik universalus, ir, galimas daiktas, kad šio gesto atsiradimas siekia ankstyvąją vaikystę. O kai kurie gestai atėję net iš pirmykštės bendruomenės praeities, pvz., šypsena pirmine prasme reiškè grasinimą (pažiūrèkite, kokiose situacijose „šypsosi“ gyvūnai...), bet šiandien ji dažniausiai reiškia pasitenkinimą arba geranoriškumą.

Skirtingų tautų neverbaliniai ženklai skiriasi. Tas pats gestas vienoje tautoje gali turèti konkrečią prasmę, kitoje jis gali nereikšti nieko arba reikšti visai kitą dalyką. Kartais sunku pasakyti, ar gestas yra genetiškai nulemtas, ar kultūriškai ịgytas.

Neverbalinė komunikacija (nežodinè, arba kūno, kalba) - tai kūno komunikacijos forma, išreikšta nesąmoningais arba sąmoningais gestais ir pozomis. Neverbalinè kalba padeda tada, kai žodžiai nedaro pakankamo efekto. Gestas gali būti iš sielos gelmių einantis signalas, kurio perduoti žodžiais neįmanoma (pvz., tylus atsisveikinimas su ligoniu, pažiūrint ị akis, linktelint galva, suspaudžiant ranką). Kartais gestai pasako daugiau negu žodžiai. Nebylūs signa- lai gali kalbèti garsiau už žodžius. Tyrimais nustatyta, kad nežodiniais signalais perduodama didžioji dalis žmogaus siunčiamos informacijos.

Priežastys, dèl kurių nežodinè komunikacija visuomet susilaukia ypatingo demesio ir tarp mokslininkų, ir bendraujant kasdieniame gyvenime:

a) neverbalinè kalba yra universalesne (gali nemokèti jokios kitos kalbos ir apskritai - nemokèti kalbèti, bet pagal kūno kalbą gali paaiškinti, kad esi alkanas, skauda ar net paklausti kelio); be to, įvairių kultūrų atstovai pagrindines emocijas išreiškia tokia pačia mimika;

b) nežodinè kalba yra įtikinamesne. Mes kalbame balsu, tačiau bendraujame visu kūnu;

c) patvirtina tai, ką partneris išsako žodžiais arba - priešingai; neverbalinè kalba yra sunkiau paslepiama, išduodanti jausmus, emocijas; tiesiogiai rodanti fiziologines reakcijas, galinti išryškinti tai, ką bendraudami norètume nuslèpti; atskleidžianti emocinès būsenos kitimą bendraujant;

d) teikia informacija apie pokalbio dalyviu emocinę būsena. Tai pats paprasčiausias būdas perduoti nepasitenkinimą, pasitenkinimą, skausmą, simpatiją ar antipatiją vienas kitam. Vaikai puikiai sugeba atsiskleisti kūno kalba, prieš išmokdami žodinę kalbą;

e) parodo emocinès būsenos kitima bendravimo metu;

f) daugiausia lemia pirmaji ispüdį-dalykiniuose santykiuose kuria pasitikejimą, arba priešingai, sukelia nepasitikèjimą. Nežodinè kalba patvirtina tai, ką partneris išsako žodžiais, arba priešingai.

Taigi kūno kalboje visuomet atsispindi mūsų vidinis nusiteikimas, minčių išraiška. Todèl turime dirbti su savi$\mathrm{mi}$ - reikia stengtis būti ramiam, santūriam, oriam, neịsitempusiam, savimi pasitikinčiam.

Jeigu verslo derybose, dalykiniame pokalbyje taikysime spaudimą, oponentas, pajutęs $\mathrm{ji}$, ims trauktis - nesulauksime geidžiamo poveikio rezultato. Visos verbalinio ir neverbalinio poveikio priemonès nueis niekais, jei jose bus bent mažiausiu spaudimo, prievartos elementų. Gerų rezultatų galèsime pasiekti tik tada, kai dèmesio centre bus ne sandoris, bet ji sudarantis žmogus (Spies 2006: 190). Reikia kontroliuoti savo kūną - ar jis nesiunčia oponentui kokiu nors lengvai pastebimų ženklų apie mūsų norus jo atžvilgiu. Jeigu jis pajus, kad yra „stumiamas ị kampą“, jūsų elgesys oponentui atrodys netinkamas ir įkyrus.

Derëjimosi procese nevalia pamiršti, kad turime nuolatos suteikti galimybę reikštis oponentui: tylèti ir atidžiai jo klausytis. Tačiau jei patys tylèsime, o mūsų kūnas bus pernelyg aktyvus, rodys nekantrumo ženklus arba per daug priartessime prie kalbančiojo ir taip trukdysime jam pasisakyti - mūsų derybos ar dalykinis pokalbis gali būti nepakankamai efektyvus. Oponentas gali susidaryti ịspūdị, kad mes tik apsimetame tylinčiu ir klausančiu, o iš tikrųjų klausomès tik iš mandagumo, nekreipiame į jị reikalingo dèmesio.

Norėdami suprasti, ką kalba mūsų oponento kūnas, turime stebèti ne tik jo judesius ir gestus, bet ir tai, kaip jie 
keičiasi. Oponento kūno kalbos pokyčiai fiksuoja akimirkas, kai keičiasi jo pozicija. Todèl derèjimosi procese reikia idèmiai stebèti, kada ir kodèl tai vyksta. Derybų partnerio, oponento kūnas yra kaip lakmuso popierèlis, kuris parodo, ar mūsų pasirinkti veiksmai, poveikio priemonès teisingi, efektyvūs, ar ne. Nèra reikalo nuolat stebèti visus oponento judesius ir mimiką, nes derybų, dalykinių pokalbiu metu reikia galvoti ir apie derybų ar pokalbio objektą. Tačiau svarbiausia užfiksuoti tas akimirkas, kai klausantis argumentų ar kontrargumentų, keičiasi oponento reakcijos.

\section{Išvados}

Plètojantis virtualioms dalykinio bendravimo priemonèms ir formoms, gyvo dalykinio pokalbio ir betarpiškų derybų reikšmè ir toliau išlieka labai svarbi. Svarbiausi ir lemtingiausi susitarimai vyksta ir dar ilgai vyks susitinkant akis $i$ akị. Dalykinis pokalbis - vienas iš geriausių ir priimtiniausių būdų įtikinti pašnekovą savo pozicijos pagrịstumu, kad jis pats sutiktų su oponento pozicija ir ją priimtų ar palaikytų.

Mokejjimas dalykiškai bendrauti, suprasti kito žmogaus, derybų partnerio psichologiją, jo ir atstovaujamos organizacijos interesus daugiausia lemia dalykinio pokalbio ir derybų sèkmę. Norint tai gerai atlikti, reikia būti įsisavinus bendravimo pagrindus, gebèti skaityti verbalinès ir neverbalinès komunikacijos ženklus, išraiškas, turèti susikūrus pasiruošimo pokalbiui ir deryboms sistemą, gebèti pateikti ir gauti informaciją, argumentuoti savo pozicijas, atsakyti i pastabas, jas neutralizuoti, perprasti, nepasiduoti manipuliacijoms ir mokèti dalykinị pokalbị ar derybas kaip dera užbaigti.

Verslo derybos, dalykinis pokalbis - asmenybių sąveika. Ši sąveika gali vykti kovos arba bendradarbiavimo forma. Galima pačiam vadovauti derejjimosi procesui arba galima leistis būti vadovaujamam kito asmens, pasiduoti ịtakai. Galima pačiam formuluoti žaidimo taisykles arba galima priimti kitos pusès primetamas sąlygas. Geras derybininkas turi mokèti atsispirti ittakai ir manipuliacijoms, argumentuoti ir apginti savo pasiūlymus, nepasiduoti spaudimui, oponentą paversti partneriu, derybinëje situacijoje iš kovos pozicijų pereiti į bendradarbiavimo vèžes.

Norint išvengti suvokimo klaidų derejjimosi procese, reikia:

a) būti lankstiems, gebėti keisti nuomonę apie žmogų, sužinojus ką nors naujo. Tai padètų išvengti aureoles efekto - kai dalis gautos informacijos apie žmogu ima dominuoti ir daro įtaką galutiniam sprendimui;

b) atidžiai stebèti ir sekti detales, skirti joms dèmesio: ir žodiniams, ir nežodiniams pranešimams bei aplinkybėms, kurioms esant bendraujama. Reikia nuolat tikrinti gaunamą informaciją ir lyginti su tuo, ką pastebime, su turima nuomone, atkreipiant dèmesi i prieštaringus dalykus, kurių apstu bendravimo procese. Taip galima išvengti apgaulingo nuoseklu- mo iliuzijos (angl. False consistency), kai nepagrịstai tikimès, kad kito asmens elgesys bus nuoseklus;

c) derejimosi procese reikia mokèti atidèti sprendimą, t. y. reikia stengtis kuo ilgiau nedaryti galutinio, lemiamo sprendimo, sukaupti kuo daugiau ir ìvairiapusiškesnès informacijos ir apgalvoti, kaip reaguoti;

d) skirti laiko papildomai informacijai rinkti, kuri padètų susidaryti objektyvesnę nuomonę;

e) nepasiduoti pirmojo įspūdžio (pradmès) ir baigmès poveikiui. Daugeliu tyrimų nustatyta, kad ir pačius pirmuosius, ir paskutinius žmonių žodžius bei poelgius ịsimename geriau nei vidurinius ir jais labiau pasitikime spręsdami apie žmones;

f) pabandyti ịsijausti - pažvelgti ị situaciją kito žmogaus akimis, suprasti jo padetit. Reikia stengtis rasti ne vieną, bet keletą skirtingų paaiškinimų, kodèl žmogus pasielge vienaip, o ne kitaip, atkreipti dèmesị ir ị vidinius, ir ị išorinius jo elgesi galinčius lemti veiksnius.

Priežastys, dèl kurių nežodinè komunikacija visuomet susilaukia ypatingo dèmesio ir tarp mokslininkų, ir tobulinant derybininkų elgesį derèjimosi procese:

a) neverbalinè kalba yra universalesne;

b) neverbalinè kalba yra įtikinamesnè. Nežodinè kalba patvirtina tai, ką partneris išsako žodžiais, arba priešingai;

c) neverbalinè kalba yra sunkiau paslepiama, išduodanti jausmus, emocijas;

d) teikia informacija apie pokalbio dalyviu emocine būsena - perduodamas nepasitenkinimas, pasitenkinimas, skausmas, simpatija ar antipatija vienas kitam ir kt.;

e) parodo emocinès būsenos kitima bendravimo metu;

f) daugiausia sudaro pirmaji isspüdị - dalykiniuose santykiuose iš pat pradžių kuria pasitikèjimą arba priešingai, sukelia nepasitikèjimą.

Derëjimosi procese svarbu išlaikyti pokalbio dinamiškumą. Tam gali padèti tam tikrų detalių, elementų sureikšminimas.

Derejimosi procese labai svarbu fiksuoti tas akimirkas, kai klausantis mūsų argumentų ar kontrargumentų, keičiasi oponento reakcijos, kurios parodo, ar mūsų pasirinkti veiksmai, poveikio priemonès yra teisingi, efektyvūs, veiksmingi ar ne.

\section{Literatūra}

Aguinis, H.; Simonsen, M. M.; Pierce, C. A. 1998. Effects of nonverbal behavior on perceptions of power bases, Journal of Social Psychology 138(4): 455-469. http://dx.doi.org/10.1080/00224549809600400

Anderson, P. A.; Bowman, L. L. 1999. Positions of power: nonverbal influence in organizational communication, in Guerrero, L. K.; DeVito, J. A.; Hecht, M. L. (Eds.). The Nonverbal Communication Reader: Classic and Contemporary Readings. Prospect Heights, IL: Waveland, 317-334. 
Bailenson, J. N.; Beall, A. C. 2006. Transformed social interaction: exploring the digital plasticity of avatars, in Schroeder, R.; Axelsson, A. (Eds.). Avatars at Work and Play: Collaboration and Interaction in Shared Virtual Environments. Berlin, Germany: Springer-Verlag, 1-16.

http://dx.doi.org/10.1111/j.1468-2958.2005.tb00881.x

Bailenson, J. N.; Beall, A. C.; Blascovich, J.; Loomis, J.; Turk, M. 2005. Transformed social interaction, augmented gaze, and social influence in immersive virtual environments, Human Communication Research 31: 511-537. http://dx.doi.org/10.1162/1054746041944803

Bailenson, J. N.; Beall, A. C.; Loomis, J.; Blascovich, J.; Turk, M. 2004. Transformed social interaction: decoupling representation from behavior and form in collaborative virtual environments, PRESENCE: Teleoperators and Virtual Environments 13(4): 428-441. http://dx.doi.org/10.1162/105474601753272844

Bailenson, J. N.; Blascovich, J.; Beall, A. C.; Loomis, J. M. 2001. Equilibrium revisited: mutual gaze and personal space in virtual environments, PRESENCE: Teleoperators and Virtual Environments 10: 583-598.

http://dx.doi.org/10.1177/0146167203029007002

Bailenson, J. N.; Blascovich, J.; Beall, A. C.; Loomis, J. M. 2003. Interpersonal distance in immersive virtual environments, Personality and Social Psychology Bulletin 29: 1-15.

Bargh, J. A. 1994. The four horsemen of automaticity: awareness, intention, efficiency, and control in social cognition, in Wyer, R. S.; Scrull, T. K. (Eds.). Handbook of Social Cognition: Basic Processes Vol. 1. Hillsdale, NJ: Lawrence Erlbaum Associates, 1-40.

Bucy, E. P. 2000. Emotional and evaluative consequences of inappropriate leader displays, Communication Research 27(2): 194-226. http://dx.doi.org/10.1177/009365000027002004

Burgoon, J. K.; Bacue, A. E. 2003. Nonverbal communication skills, in Greene, J. O.; Burleson, B. R. (Eds.). Handbook of Communication and Social Interaction Skills. Mahwah, NJ: Lawrence Erlbaum Associates, 179-220.

Burgoon, J. K.; Berger, C. R.; Waldron, V. R. 2000. Mindfulness and interpersonal communication, Journal of Social Issues 56(1): 105-127. http://dx.doi.org/10.1111/0022-4537.00154

Burgoon, J. K.; Dunbar, N. E. 2000. An interactionist perspective on dominance-submission: interpersonal dominance as a dynamic, situationally contingent social skill, Communication Monographs 67(1): 96-121.

http://dx.doi.org/10.1080/03637750009376497

Cherulnik, P. D.; Donley, K. A.; Wiewel, T. R.; Miller, S. R. 2001. Charisma is contagious: the effect of leaders' charisma on observers' affect, Journal of Applied Social Psychology 31(10): 2149-2159.

http://dx.doi.org/10.1111/j.1559-1816.2001.tb00167.x

Choi, V. S.; Gray, H. M.; Ambady, N. 2005. The glimpsed world: unintended communication and unintended perception, in Hassin, R. R.; Uleman, J. S.; Bargh, J. A. (Eds.). The New Unconscious. New York: Oxford University Press, 309-333.

Driskell, J. E.; Salas, E. 2005. The effect of content and demeanor on reactions to dominance behavior, Group Dynamics: Theory, Research, and Practice 9(1): 3-14. http://dx.doi.org/10.1037/1089-2699.9.1.3
Dunbar, N. E.; Burgoon, J. K. 2005a. Measuring nonverbal dominance, in Manusov, V. (Ed.). The Sourcebook of Nonverbal Measures: Going Beyond Words. Mahwah, NJ: Lawrence Erlbaum Associates, 361-374. http://dx.doi.org/10.1177/0265407505050944

Dunbar, N. E.; Burgoon, J. K. 2005b. Perceptions of power and interactional dominance in interpersonal relationships, Journal of Social and Personal Relationships 22(2): 207-233.

Ekman, P. 1997. Expression or communication about emotion, in Segal, N. L.; Weisfeld, G. E. (Eds.). Uniting Psychology and Biology: Integrative Perspectives on Human Development. Washington, DC: American Psychological Association, 315-338. http://dx.doi.org/10.1037/10242-008

Ginevičius, R. 2009. Socioekonominių sistemų būklès kiekybinio įvertinimo problematika, Verslas: teorija ir praktika [Business: Theory and Practice] 10(2): 69-83. http://dx.doi.org/10.3846/1648-0627.2009.10.69-83

Hecht, M. L.; DeVito, J. A.; Guerrero, L. K. 1999. Perspectives on nonverbal communication. Codes, functions, and contexts, in Guerrero, L. K.; DeVito, J. A.; Hecht, M. L. (Eds.). The Nonverbal Communication Reader: Classic and Contemporary Readings. Prospect Heights, IL: Waveland, 3-18.

Izard, C. E. 1997. Emotions and facial expressions: a perspective from differential emotions theory, in Russell, J. A.; Fernández-Dols, J. M. (Eds.). The Psychology of Facial Expression: Studies in Emotion and Social Interaction. New York: Cambridge University Press, 57-77. http://dx.doi.org/10.1017/CBO9780511659911.005

Jurevičienė, D.; Komarova, A. 2010. Darbuotojo konkurencingumo vertinimo teoriniai aspektai, Verslas: teorija ir praktika [Business: Theory and Practice] 11(2): 124-133. http://dx.doi.org/10.3846/btp.2010.14

Krumhuber, E.; Kappas, A. 2005. Moving smiles: the role of dynamic components for the perception of the genuineness of smiles, Journal of Nonverbal Behavior 29(1): 3-24. http://dx.doi.org/10.1007/s10919-004-0887-x

Lobanova, L. 2009. Žmogiškųjų išteklių vadybos vertè žiniomis grindžiamoje visuomeneje, Verslas: teorija ir praktika $[\mathrm{Bu}-$ siness: Theory and Practice] 10(3): 233-246. http://dx.doi.org/10.3846/1648-0627.2009.10.223-232

Manusov, V. 1999. Stereotypes and nonverbal cues. Showing how we feel about others during cross-cultural interactions, in Guerrero, L. K.; DeVito, J. A.; Hecht, M. L. (Eds.). The Nonverbal Communication Reader: Classic and Contemporary Readings. Prospect Heights, IL: Waveland, 388-394.

Parkinson, B.; Fischer, A. H.; Manstead, A. S. R. 2005. Emotions in Social Relations: Cultural, Group, and Interpersonal Processes. New York: Psychology Press.

Peleckis, K.; Peleckienè, V.; Mažeikienè, A. 2010. The main factors determining the choice of self-presentation strategies in negotiations and business meetings, Verslas: teorija ir praktika [Business: Theory and Practice] 11(4): 353-361. http://dx.doi.org/10.3846/btp.2010.38

Peleckis, K.; Mažeikienè, A. 2009. Strategies of self-presentation in the business meetings and negotiation, Verslas: teorija ir praktika [Business: Theory and Practice] 10(4): 322-329. http://dx.doi.org/10.3846/1648-0627.2009.10.322-329

Peleckis, K.; Peleckienė, V.; Mažeikienè, A. 2011a. Manager's training for business meetings and negotiations: strategies of 
self-presentation / K. Peleckis, V. Peleckiene, A. Mazeikiene // Труды 9-й международной научно-практической интернет-конференции <<Преподаватель высшей школы в XXI веке > = International scientific-practical INTERNET conference "The teacher of a higher school in the 21-st century"/ Ростовский государственный университет путей сообщения. Ростов-на-Дону: РГУПС. 9(2): 159-171. ISBN 978-5-88814-290-5.

Peleckis, K.; Peleckienè, V.; Mažeikienè, A. 2011b. Factors, determining manager's self-presentation strategy in business meetings ang negotiations / K. Peleckis, V. Peleckiene, A. Mazeikiene // Труды 9-й международной научнопрактической интернет-конференции $<<$ Преподаватель высшей школы в XXI веке>> = International scientificpractical INTERNET conference "The teacher of a higher school in the 21-st century” / Ростовский государственный университет путей сообщения. Ростов-на-Дону: РГУПС. 9(2): 172-186. ISBN 978-5-88814-290-5.
Pipirienė, V.; Maciukevičienė, L. 2011. Komunikacija ir derybos - esminè tarptautinio verslo pletotès prielaida, Verslas: teorija ir praktika [Business: Theory and Practice] 12(3): 296-302. http://dx.doi.org/10.3846/btp.2011.30

Riggio, R. E. 2005. Business applications of nonverbal communication, in Riggio, R. E.; Feldman, R. S. (Eds.). Applications of Nonverbal Communication. Mahwah, NJ: Lawrence Erlbaum Associates, 119-138.

Smaliukienė, R.; Korsakienè, R.; Prakapas, R. 2010. Darbuotojų konsultaciniai gebejjimai: raiška ir ugdymo problemos, Verslas: teorija ir praktika [Business: Theory and Practice] 11(1): 12-19. http://dx.doi.org/10.3846/btp.2010.02

Spies, S. 2006. Kūno kalba. Vilnius: Vaga.

Zabielavičienė, I. 2008. Inovacijų komandos formavimasis ir jos elgsenos modifikavimas, Verslas: teorija ir praktika [Business: Theory and Practice] 9(4): 261-271. http://dx.doi.org/10.3846/1648-0627.2008.9.261-271

Kęstutis PELECKIS. Associate Professor, Doctor of social sciences (Economics), Dept of Enterprise Economics and Management, Vilnius Gediminas Technical University. Author of more than 100 publications. Research interests: increase of efficiency in business meetings and negotiations.

Valentina PELECKIENĖ. Associate Professor, Doctor of social sciences (Economics), Dept of Social Economics and Management, Vilnius Gediminas Technical University. Author of more than 40 publications. Research interests: increase of efficiency in business meetings and negotiations.

Aistė MAŽEIKIENĖ. Master of Organisational Psychology. Lecturer at Mykolas Romeris University, Department of Psychology. Author of more than 80 publications. Research interests: human resurse management, psychology of effective management, increase of efficiency in business meetings and negotiations. 